\title{
Improvement of the Loading Capacity of Narrow Coal Pillars and Control Roadway Deformation in the Longwall Mining System. A Case Study at Khe Cham Coal Mine (Vietnam)
}

Le QUANG PHUC ${ }^{1,2, *)}$, V. P. ZUBOV ${ }^{2)}$, Phung MANH DAC ${ }^{3)}$

\footnotetext{
1) Hanoi University of Mining and Geology, Hanoi, Vietnam; email: lequangphuc68@gmail.com

2) Saint-Petersburg Mining University (Mining University), Russia; email: spggi_zubov@mail.ru

3) Association of Mining Science And Technology Vietnam, Vietnam; email: dacphungmanh@gmail.com
}

\section{http://doi.org/10.29227/IM-2020-02-15}

Submission date: 06-03-2020 | Review date: 22-09-2020

\section{Abstract}

Currently, the application of coal pillars to protect an adjacent roadway is a common method in Vietnam when exploiting according to the longwall system. Therefore, the width of a coal pillar is an important issue for the stability of a roadway. In order to reduce coal loss in these coal pillars, they tend to be designed in a narrow coal pillar style but still have to ensure that the adjacent roadway can meet safe coal production conditions. The stability of roadways and coal pillars is related to many factors such as technical mechanical characteristics, physical and mechanical properties of coal, stress environment and support methods. The bearing structure of the coal pillar and the around rock a roadway is analyzed and it has been shown that enhancing roadway support and improving the carrying capacity of coal pillars can control the deformation of the surrounding rock. A study related to the stability and safety of roadways and small coal pillars in the longwall mining system has been carried out. Stabilization factors have been considered, especially the state of stress in the coal pillars and the deformation of the roadway. By applying the numerical simulation method, the stress of the coal pillar and the deformation of the adjacent roadway under different supporting solutions were analyzed and evaluated. By using this method, the rock bolt roadway support solution combined with the long cable bolt in the roadway roof and the coal pillar was selected in the safe condition of the mining process. Because cable bolt can improve the flexibility of the coal pillar such as: reducing the size of the plastic area on both sides of the pillar; enhancing coal pillar stability in the core area by providing great drag and tensile for coal pillars; contributing to improving the anchor point fixation of rock bolt. The conclusions obtained may provide a certain reference parameters to improve mining efficiency and labor safety in underground coal mines.

Keywords: roadway support, numerical modelling, roadway boundary displacement, coal pillar stability

\section{Introduction}

In underground coal mining, an increase in coal recovery rate can be achieved by not leaving protective coal pillars in the gob or reducing its size to the minimum limit (Zubov V. P., 2018). At the current Vietnamese underground coal mines, most coal seams are prepared and exploited with the longwall mining system. To reduce coal loss in coal pillars, coal pillars tend to be designed in a narrow coal pillar style. In this condition, the task of improving the load capacity of the coal pillar and the stability of the roadway is important for the safety and efficient production of coal mines. Failure of the coal pillar will lead to occupational safety risks. Currently, methods of controlling roadway stability have been applied in Vietnam's underground coal mines such as steel arches, short rock bolts (Dao Viet Doan et al., 2019). In some cases, these methods are effective for controlling roadway deformation. However, in the case of the roadway arranged along the narrow coal pillar of the longwall mining system, such conventional support systems often fail, the roadway is greatly deformed, as shown in Figure 1. In this case, roadway widening is often necessary to meet the requirements exploited of the next mining panel, thus increasing costs, or even bringing potential risks to production.

So far, roadway stability has been concerned with its support system and the load capacity of the adjacent coal pillar.
In order to improve the load capacity of narrow coal pillars, studies mainly focus on aspects such as the width of coal pillars. Many mechanical models have been proposed to analyze the stability of coal pillars such as the nonlinear rheology model of Wang et al. [Dong Wang et al., 2019], simple spring model simulation and flexural roof model ( $\mathrm{Mroz} \mathrm{Z}$. et al., 1989). In addition to mechanical models, mathematical models have also been introduced; for example, logistic regression methods and symmetric matrices (Salamon, 1970; Wattimena R. et al., 2013). In addition, the issues of ensuring the stability of roadways and improving the load capacity of narrow coal pillars were also conducted by studies (e.g., (Li C. et al., 2012), (Bo Wang et al., 2019), (Li M. at al., 2012), (Zubov V. P. et al. 1998)) based on the law of limit equilibrium, numerical simulation, and experimental research. These studies all reveal that an intact area exists at the centre of the coal pillar and the stability of the pillar depends on it. Therefore, for improving the loading capacity of narrow coal pillars and control roadway deformation, it is necessary to increase the stability at the centre of the coal pillars.

In this paper, we consider a $7 \mathrm{~m}$ width of coal pillar along the gob area of a previously extracted coal panel. We chose the width of coal pillar $7 \mathrm{~m}$ to study because in this case, when the roadway is not supported, the stress distributed on the coal pillar is greater than the primary stress and less than the stress 


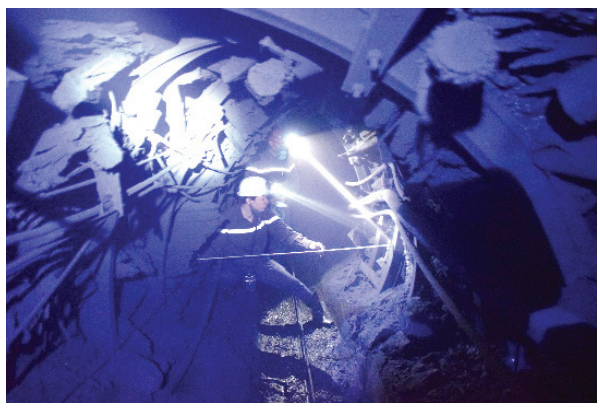

a)

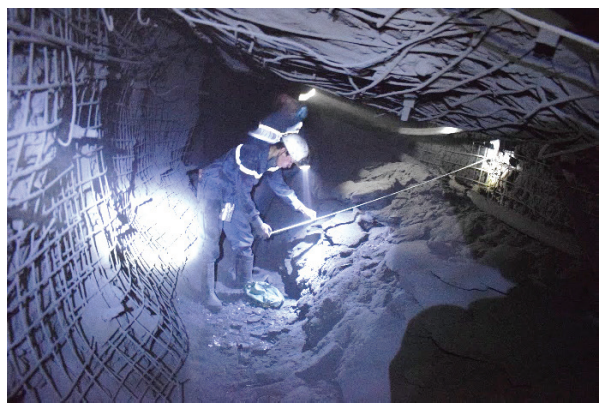

b)

Fig. 1. Investigation of failure and deformation of the roadway arranged next to the narrow coal pillar in the longwall mining system at Khe Cham coal mine: a - roadway support with steel support frame SVP; b - roadway support with short rock bolts

Rys. 1. Badanie zniszczenia i odkształcenia wyrobisk złożowych przy wąskim filarze w ścianowym systemie kopalni Khe Cham: a - podpora wyrobisk ze stalową ramą wsporczą SVP; b - podparcie wyrobisk z krótkimi kotwami do skał

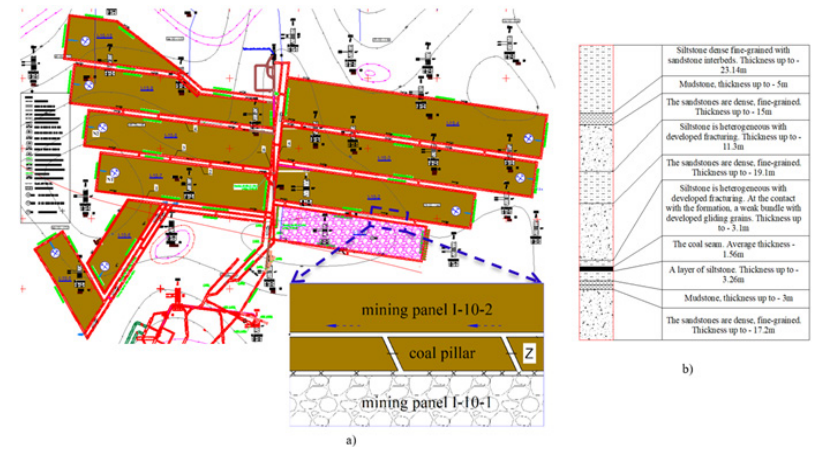

Fig. 2. Layout and lithology of the working faces of the coal seam 10: $a$ - layout of the working faces; $b$ - lithological profile Rys. 2. Układ położenia i struktury litologii ścian roboczych pokładu węgla 10: a - układ ścian roboczych; b - przekrój litologiczny

on the coal seam. According to studies (e. g., (Lifeng Li et al., 2018), (Wang P. et al., 2019), (Wu Hai et al., 2015), (Zubov, 2013)), this condition makes the coal pillar stable while coal loss is minimal. The coal pillar used for protecting the roadway and the extracted coal panel only exists along one side. The numerical model using the finite element method was used to analyze the stress distribution inside the coal pillar, the deformation on the roadway boundary and on both sides of the pillar.

Here, the ventilation roadway and coal pillars are located in a coal mining panel with a gently sloping coal seam and average thickness analyzed by a 2D numerical model. In this model, stress distribution and failure zone are analyzed in detail based on the mining conditions of I-10-2 mining panel at ten seams of Khe Cham coal mine, Quang Ninh coal basin, Vietnam. The I-10-2 mining panel is a long wall mining face, and in the south of this mining panel is an I-10-1 mining panel, where coal has been extracted (Figure 2). The height of the ground is from +58 to $+78 \mathrm{~m}$, and the height of the working face is from $-250 \mathrm{~m}$ to $-286 \mathrm{~m}$. The mining face is $445 \mathrm{~m}$ along the strike and 140 $\mathrm{m}$ along the dip. The average thickness of the coal seam is 1.56 $\mathrm{m}$, and the dip angle is 80 . The main roof is sandstone or fine sandstone with an average thickness of $19.1 \mathrm{~m}$. The immediate roof is siltstone with a thickness of $3.1 \mathrm{~m}$. The immediate floor is siltstone and mudstone with a thickness of up to $6.26 \mathrm{~m}$. The main floor is sandstone with a thickness of $17.2 \mathrm{~m}$. The properties of the rocks are given in Table 1.

A support mechanism to control the stability of roadways and coal pillars was analyzed including: (1) use steel support
"SVP" to control roadway stability; (2) use rock bolts to control roadway stability; (3) use rock bolts to control roadway stability and long cable bolts to fix anchor points and limit the separation between the two side plastic areas and the stabilizing zone in the centre of the coal pillar.

\section{Research method}

With different roadway support solutions, the stress distribution on the narrow coal pillar and the deformation of the roadway boundaries are also different. To study this problem, the finite element method was used with the Phase2 program of the Rocscience of Canada (Rocscience, 2016). Phase2 program has the advantage of studying stress distribution and stress change in mining. In this article, the Phase 2 program will be used to study the difference of stress distribution, roadway deformation in each specific case.

Based on the geological and technical conditions of the I-10-2 working face, four different 2D models were modelled by Phase 2 program with a $7 \mathrm{~m}$ width of coal pillar corresponding to the following cases: (1) the roadway and the coal pillar without support (the following is called case 1); (2) supporting the roadway by steel frames (case 2); (3) supporting the roadway by rock bolts (case 3); (4) supporting the roadway by rock bolts combined with long cable bolts at roadway roofs and at coal pillars (case 4 ). All these numerical models use a width of $400 \mathrm{~m}$ and a height of $150 \mathrm{~m}$ (Figure 3 ). At the top of the models, a vertical load ( $\mathrm{p}=\gamma \mathrm{H}=0.0238$ $\mathrm{x} 300=7.14 \mathrm{MPa}$ ) was applied to simulate weight overload. The Mohr-Coulomb model method is made of elastic-plastic 
Fig. 2. Layout and lithology of the working faces of the coal seam 10: $a$ - layout of the working faces; $b$ - lithological profile Rys. 2. Układ położenia i struktury litologii ścian roboczych pokładu węgla 10: a - układ ścian roboczych; b - przekrój litologiczny

\begin{tabular}{|c|c|c|c|c|c|c|}
\hline Strata & $\begin{array}{c}\text { Tensile } \\
\text { strength (MPa) }\end{array}$ & $\begin{array}{c}\text { Elastic modulus } \\
(\mathrm{MPa})\end{array}$ & Poisson ratio & Cohesion (MPa) & $\begin{array}{c}\text { Friction angle } \\
(\mathrm{deg})\end{array}$ & Density $\left(\mathrm{kg} / \mathrm{m}^{3}\right)$ \\
\hline Sandstone & 1,6 & 21100 & 0,28 & 3,2 & 38 & 2780 \\
\hline Siltstone & 0,9 & 16500 & 0,28 & 2,1 & 30 & 2250 \\
\hline Mudstone & 1,2 & 13900 & 0,3 & 3 & 26 & 2250 \\
\hline Coal & 0,4 & 4300 & 0,35 & 0,9 & 19 & 1250 \\
\hline
\end{tabular}

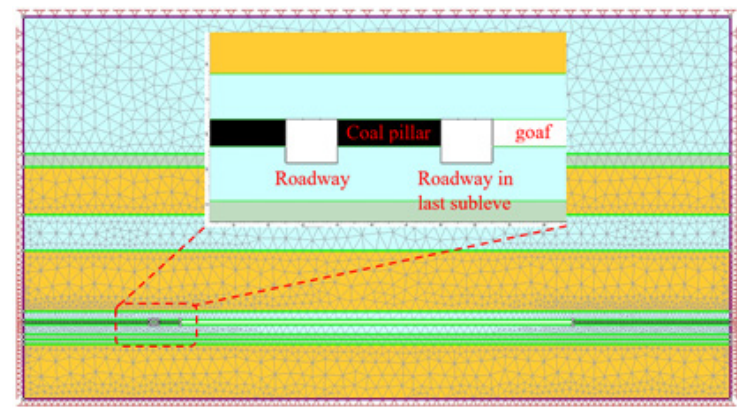

Fig. 3. Plot of the two-dimensional model

Rys. 3. Schemat dwuwymiarowego modelu

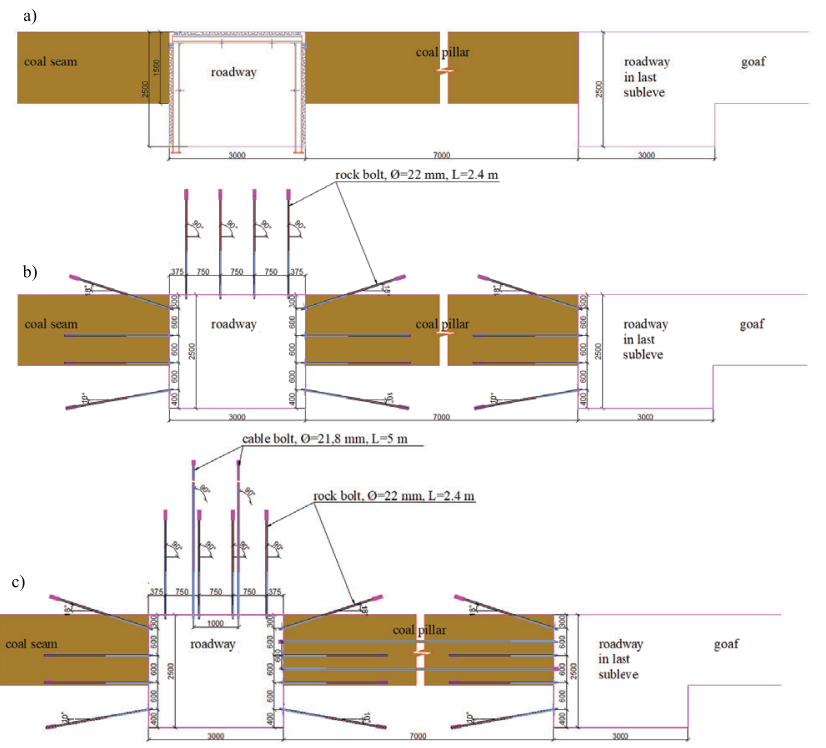

Fig. 4. Three case studies on the stability and displacement of the roadway and the coal pillars: $\mathrm{a}$ - supporting the roadway by steel support frames; $\mathrm{b}$ - supporting the roadway by rock bolts; $\mathrm{c}$ - supporting the roadway by rock bolts combined with long cable bolts at roadway roofs and at coal pillars

Rys. 4. Trzy typowe przypadki dotyczące stateczności i przemieszczenia wyrobisk złożowych oraz filarów węglowych: a - podparcie wyrobisk stalowymi ramami nośnymi; b - podparcie wyrobisk kotwami do skał; c - podparcie wyrobisk kotwami do skał połączonymi z długimi kotwami linowymi na stropie i na filarach węglowych

material with the rule of non-associated flow which is used for layer roofs and floors. The roadways in these models are rectangular with dimensions of $3.0 \mathrm{~m}$ wide and $2.5 \mathrm{~m}$ high. The coefficients of horizontal and vertical pressure are taken respectively 1.0 and 1.0. Horizontal displacements are fixed at the internal boundary while vertical displacements are fixed at the bottom boundary. The modelling processes are as follows: (1) initial state modelling caused by gravity; (2) modelling the excavation entry in the last panel 10-I-2 with various roadway support structures such as:

- roadway support structure by the steel support frame;

- roadway support structures by rock bolts;

- roadway support structure by rock bolts combined with long cable bolts at roadway roof and at coal pillar.
In the model, we use support steel type C180x18,2 (U-shaped steel) with a weight of $18.2 \mathrm{~kg} / \mathrm{m}$, the moment of inertia $4.83 \times 10-7 \mathrm{~m}^{4}$, young's modulus $200000 \mathrm{MPa}$, the distance between frames supporting is $0.7 \mathrm{~m}$. This steel has similar properties to SVP-17 steel, which is being used in Vietnam's underground coal mines. Rock bolts are made of steel bars capable of strong deformation. The diameter of each rock bolt is $22.0 \mathrm{~mm}$ and a length of $2.4 \mathrm{~m}$. The inside length of rock bolts at the roof and roadway walls is $2.3 \mathrm{~m}$, the exposed length is $0.1 \mathrm{~m}$, the tensile strength of rock bolts is $260 \mathrm{KN}$, the layout space is $750 \mathrm{~mm} \times 800 \mathrm{~mm}$ at the roadway roof and $600 \mathrm{~mm} \times 800 \mathrm{~mm}$ at the roadway wall. The diameter of each cable bolts are $21.8 \mathrm{~mm}$ and $5 \mathrm{~m}$ long at the roadway roof and $7 \mathrm{~m}$ at the coal pillar made of 19 strong steel cables. The inside 


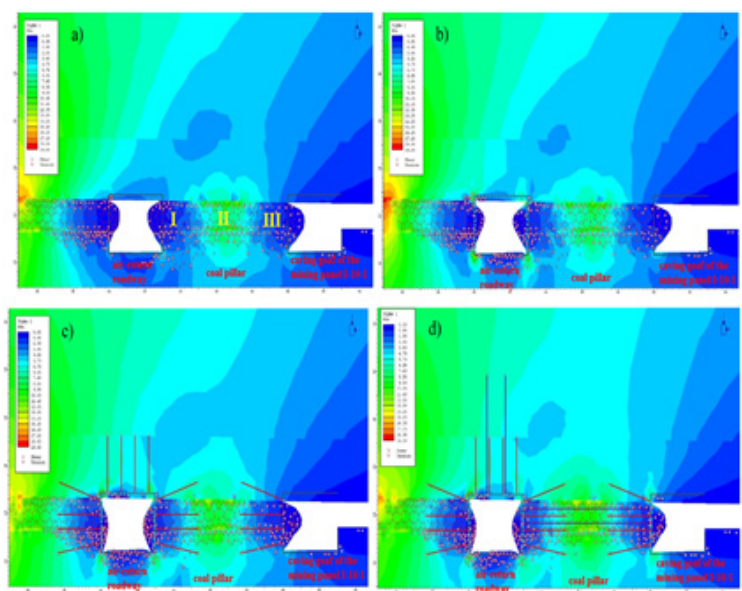

Fig. 5. Vertical stress distribution of roadway surrounding rock and of the coal pillar, a - roadway and coal pillar are not supported; b - supporting the roadway by steel support frames; $\mathrm{c}$ - supporting the roadway by rock bolts; $\mathrm{d}$ - supporting the roadway by rock bolts combined with long cable bolts at roadway roofs and at coal pillars

Rys. 5. Rozkład naprężeń w pionie górotworu otaczającego wyrobiska i filary węglowe a - Wyrobisko i filar węglowy nie są obsługiwane; b - podparcie wyrobiska stalowymi ramami wsporczymi; c - podparcie wyrobiska kotwami do skał; d - podparcie wyrobiska kotwami do skał w połączeniu z długimi kotwami linowymi na stropie i na filarach węglowych

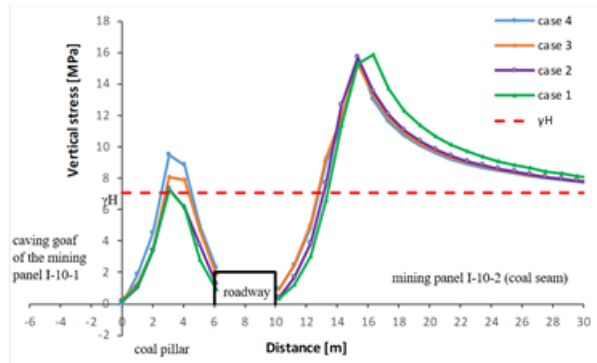

Fig. 6. Chart of vertical stress distribution on coal pillar and in the coal seam with different roadway support solutions Rys. 6. Wykres rozkładu naprężeń pionowych na filarach węglowych i w pokładzie przy różnych rozwiązaniach podparcia wyrobisk

length of the cable bolt into the roadway roof is $4.8 \mathrm{~m}$ and in the coal pillar is $6.8 \mathrm{~m}$, the exposed length is $0.2 \mathrm{~m}$, the tensile strength of cable bolts is $610 \mathrm{KN}$. The layout space is $1000 \mathrm{~mm}$ $\mathrm{x} 1000 \mathrm{~mm}$ at the roadway roof and $600 \mathrm{~mm} \times 1000 \mathrm{~mm}$ at the coal pillar (Https://www.dsiunderground.com.au). The passport of roadway support and coal pillar is shown in Figure 4.

Figure 3 shows a 2D model frame that simulates the operational state of the mining area. The mining panels applied a longwall mining system. The pillar between mining faces I-10-1 and I-10-2 and roadway are the focus of this investigation.

\section{Results and discussion \\ Vertical stress distribution on coal pillars}

The vertical stress distribution of surrounding rock corresponding to the different roadway support and coal pillar support solutions is shown in Figure 5. The vertical stresses at the roof and the floor of the roadway are in a state of low stress, and the stresses here basically do not change much. Highstress concentration is on the side of the roadway, and they differ in relation to the different ways supporting roadway. In particular, the stress inside the coal pillar has a marked change, and there are always 3 areas including a fracture area "I" located on the roadway side; a stable area "II" in the centre of the coal pillar; and a collapsed zone "III" located on the gob side. Region II is crucial to the stability of the coal pillar.
Initially, when the roadway was not supported, the high-stress concentration area (stable area II) in the centre coal pillar was narrow, and the stress area decreased (regions I, III) with a fairly wide width on both sides of the coal pillar. When the roadway is supported by different methods, the stress concentration area in the core of the coal pillar is strengthened and expanded. This proves that the elasticity of the stable area in the coal pillar is expanded, accompanied by an increase in its bearing capacity.

The vertical stress distribution amplitude on the coal pillar with various support solutions is shown in Figure 6. According to this result, a region of maximum stress appears at the centre of the coal pillar and increases gradually from case 1 to case 4 . When the roadway is supported by steel support frames, the vertical stresses on the coal pillar do not change much compared to the case without support. The maximum vertical stress peak of the coal pillar is $7.23 \mathrm{MPa}$, and the elastic core area exists very small inside the coal pillar; the bearing capacity of the coal pillar is weak. When the roadway is supported by rock bolts, the vertical stress increases, and the maximum stress reaches $8.05 \mathrm{MPa}$. This increase in stress means that the bearing strength of the coal pillar is strengthened to resist pressure from the rock strata. The elastic core area is expanded inside the coal pillar. When the roadway and coal pillars are supported by rock bolts in combination with long cable bolts, the stress peak on the coal pillar reaches 9.7 


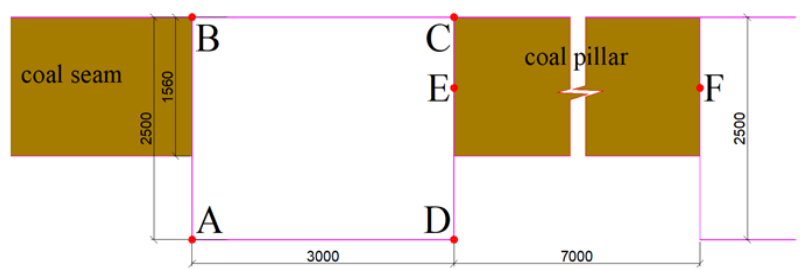

Fig. 7. Diagram surveying the displacement of coal pillars and roadway borders Rys. 7. Schemat przemieszczenia filarów węglowych i granic wyrobisk

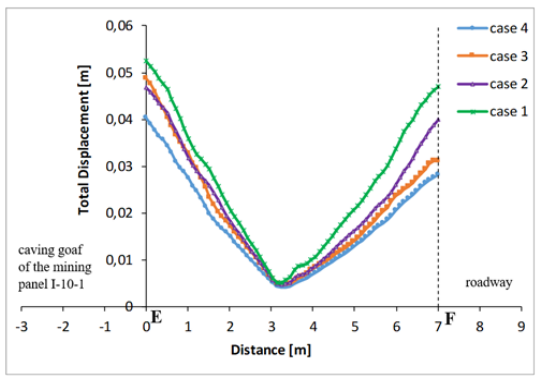

Fig. 8. Total displacement on coal pillars with different support solutions Rys. 8. Całkowite przemieszczenie na filarach węglowych przy różnych rozwiązaniach podporowych

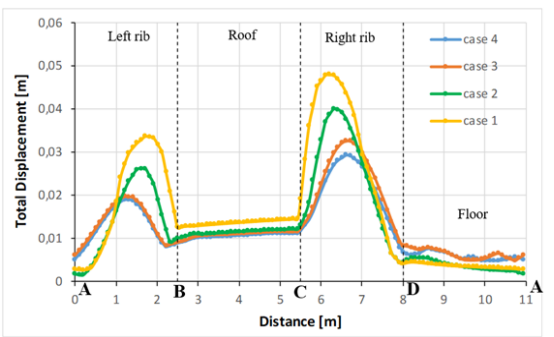

Fig. 9. Total displacement on roadway borders with different support solutions

Rys. 9. Całkowite przemieszczenie na granicach chodników przy różnych rozwiązaniach podporowych

$\mathrm{MPa}$ and is higher than in the remaining cases but smaller than the stress peak on the coal seam. This means that the coal pillar is strengthened but does not change the place where the main bearing is the coal seam. Therefore, this condition is the most stable of coal pillar and roadway.

According to research (Lifeng Li et al., 2018; Hongwei Zhang et al., 2018) the width of the narrow coal pillar is divided into three regions as described in the following equation:

$$
\mathrm{Z}=\mathrm{X}_{1}+\mathrm{X}_{2}+\mathrm{X}_{3}
$$

Where: B - coal pillar width, $\mathrm{m} ; \mathrm{X}_{1}$ - plastic zone width generated in the gob-side coal mass after the mining of the working face, $\mathrm{m} ; \mathrm{X}_{3}$ - effective length of the anchor bolt; and $\mathrm{X}_{2}$ - coal pillar stability coefficient, which is increased on the basis of the large coal seam thickness and is calculated on the basis of $\left(\mathrm{X}_{1}+\mathrm{X}_{3}\right)(30-50 \%)$.

The width of the region $\mathrm{X} 1$ can be calculated using the following equation:

$$
X_{1}=\frac{m \lambda}{2 \tan \varphi_{0}} \ln \left(\frac{k \lambda H+\frac{C_{o}}{\tan \varphi_{o}}}{\frac{C_{o}}{\tan \varphi_{o}}+\frac{P_{x}}{\lambda}}\right)
$$

Where: $\mathrm{m}$ - is the height of extraction, $\mathrm{m} ; \lambda$ - is the lateral stress coefficient; $\mathrm{k}$ - is the vertical coefficient of stress concentration; $\gamma$ - is the average strata bulk weight, $\mathrm{kN} / \mathrm{m}^{3}$; $\mathrm{H}$ - is the roadway burial depth, $\mathrm{m} ; \mathrm{C}_{0}-$ is the cohesion of coal; $\varphi_{0}$ - is the friction angle of coal; and Px is the supporting resistance provided by the anchor bolt to the coal wall, $\mathrm{MPa}$;

As shown in equation (2), the parameters $m, \lambda, k, \gamma, H$ depends on the geological conditions of the area, location of roadway and coal pillars. Therefore, the width of the plastic zone on both sides of the coal pillar is only governed by the friction angle $\varphi_{0}$, cohesion $\mathrm{C}_{0}$, and Px stress limit, and these parameters can be improved by the appropriate geotechnical methods. In the case of using long cable bolts to reinforce the coal pillar, it has shown outstanding advantages in these aspects. Firstly, the large resistance of cable bolts with full length can provide high limit stress to the lateral surface of the coal pillar. Second, the grout injected into the coal pillar together with the cable bolt replaced the air and water in the cracks, then filled the cement grout on the surface of the crack, thus increasing the stability of weak planes. Third, some small cracks and cracks that are too small may be closed due to the high pressure of grout injected. As a result, mechanical parameters such as friction angle and cohesion can be improved, and the width of the plastic area can be reduced, and coal pillars more stable.

\section{The displacement of the coal pillar and the stability of the roadway}

The survey diagram of the displacement of the coal pillar and the roadway boundary is shown in Figure 7. The rules of 
deformation of the coal pillar and the roadway when applying different support solutions are shown in Figures 8 and 9 (in the model only transient displacement is defined).

As shown in Figures 8 and 9, when the roadway is not supported, the displacement value at both sides of the coal pillar and at the roadway boundaries is very large. The highest displacement peak of the coal pillar toward the gob side is $52.5 \mathrm{~mm}$ and towards the roadway is $47.1 \mathrm{~mm}$. When the roadway is supported by a steel support frame, the value of the displacement peak of the coal pillar toward the gob side decreases significantly from $52.5 \mathrm{~mm}$ to $46.8 \mathrm{~mm}$ and towards the roadway is reduced to $39.9 \mathrm{~mm}$. Thus, with the support of the steel support frame in the roadway, the adjacent coal pillar has been enhanced for its load capacity. When the roadway is supported by rock bolts, the displacement peak of the coal pillar toward the gob side increases to $48.7 \mathrm{~mm}$ and towards the roadway decreases to $31.2 \mathrm{~mm}$. There is an asymmetric change between the two sides of the coal pillar, due to the impact of the buckling load and collapse of the roof rock layers, the plastic area of the coal pillar on the gob side appear many cracks and destroyed. Therefore, the anchoring capacity of rock bolts in this area is not good and leads to increased displacement. Meanwhile, on the side of the roadway, under the support of the rock bolts on the roof and at the coal pillars, and the stability in the core of the coal pillars is strengthened so the rock bolts are better anchored and the displacement of coal pillar walls is reduced. This shows that when using rock bolts to support the roadway, the stability of the roadway is better. However, due to the high peak displacement toward the gob-side of the coal pillar, it could lead to the destruction of the pillar if it exists for a long time. Therefore, to ensure the stability of the roadway and the coal pillar, it is necessary to reduce the displacement peaks on both the gob side and the roadway side of the coal pillar. Satisfying this condition, in case 4 , when using rock bolts combined with long cable bolts on roadway roof and coal pillar, the displacement peak is reduced to $28.1 \mathrm{~mm}$ toward the roadway and to $40.2 \mathrm{~mm}$ toward the gob side of the coal pillar. There is a significant reduction in this displacement because the long cable bolts through the coal pillar work to pull the two sides of the coal pillar to the centre so that it enhances the horizontal stress and reduces the horizontal displacement of the pillar. At the same time, the cement grout is injected into the coal pillar through drill holes install cable bolts, which fill the cracks in the plastic area of the coal pillar, making it possible to anchor the rock bolts is to be improved. Therefore, this case is likely to ensure the most stable coal pillar compared to the remaining cases.

Considering the displacement of the roadway boundary (Figure 9), in case the roadway is not supported, the displacement on the two walls of the roadway is very high while the displacement on the roof is small and especially the displacement on the floor is trivial. When the roadway is supported by a steel support frame, the displacement peak of the wall toward coal seam decreases from $33.7 \mathrm{~mm}$ to $26.2 \mathrm{~mm}$, and the displacement of the wall toward coal pillar decreases from $48.2 \mathrm{~mm}$ to $39.9 . \mathrm{mm}$. The displacement in the roadway roof was also reduced but not much from $14.6 \mathrm{~mm}$ to 12.1 $\mathrm{mm}$. The displacement at the floor of the roadway (near the coal pillar) increased compared to the case of unsupported roadways. This is because when there is roadway support, the pillar adjacent is strengthened steadily, so its displacement is reduced. Therefore, pressure from the strata of rock roof passes pressure through the coal pillar to the floor and causes convergence of the roadway floor.

When the roadway is supported by rock bolts, the displacement peaks at the two walls continue to decrease, the displacement at the roof does not change much but the displacement at the floor increases. Specifically, the displacement peak at the left wall decreased from $26.2 \mathrm{~mm}$ to $19.7 \mathrm{~mm}$, and the displacement peak at the right wall decreased from 39.9 $\mathrm{mm}$ to $32.6 \mathrm{~mm}$. Moreover, the peaks of this displacement tend to move towards the centre of the roadway wall. The floor displacement increased from $3.7 \mathrm{~mm}$ to $6.6 \mathrm{~mm}$ and concentrated on the sides of the roadway floor.

When the roadway and coal pillars are supported by rock bolts combined with long cable bolts, the stability of the roadway continues to be enhanced. The left wall has no displacement change compared to case 3 because there is no support of the cable bolts here. The displacement of the roof and the floor does not change much. The displacement peak at the right wall is reduced from $32.6 \mathrm{~mm}$ to $29.3 \mathrm{~mm}$. This change is because the long cable bolts in the coal pillar have increased the load capacity of the pillar and reduced its displacement.

In summary, the support of roadway and coal pillar has a great influence on the displacement of coal pillar, and roadway walls while it has a relatively small effect on the roof and floor. Based on the analysis of the deformation of the coal pillars and the rock surrounding the roadway, a reasonable support solution for the roadway and the coal pillars consider using rock bolts in combination with long cable bolts.

\section{Conclusion}

In Vietnam, coal provides the most energy for economic development and industrialization. The mining depth of underground mining is increasing rapidly, and it is difficult to exploit. The effective and safe task of exploiting coal resources has a great influence on the sustainable development of Vietnam's coal industry. In this paper, the narrow coal pillar designed to protect the adjacent roadway can reduce coal loss in the pillars. However, a narrow coal pillar can easily fail, leading to the challenge of finding a stable design solution for the mine designer. Based on a numerical model analysis of stress distribution, roadway deformation, and coal pillars, and according to the provided support techniques, we have devised a method that can enhance the stability of the pillars and roadway stability. This study has led to the following conclusions:

1. In a $7 \mathrm{~m}$ narrow coal pillar as in this case study, there are always three areas with different size and extent of damage including: "I" fracture area on the roadway side, "II" stable area in the centre of coal pillar and collapsed area "III" located on gob side. Region II stability has decisive implications on the stability of the coal pillar. Therefore, solutions to enhance the stability and expand the area of this region are necessary for the enhancement of the load capacity of the pillar.

2. Supporting the roadway by steel support frames does not bring high efficiency because of this type of support passive nature. Under heavy pressure and displacements at the roadway boundary, the steel support frame was easily destroyed, and the roadway collapsed. 
3. The supporting technology associated with conventional rock bolts cannot sustain the stability of roadways and pillars. The reason is that in the condition of narrow coal pillar, the anchor fixation points of rock bolts are in the plastic area, so the ability to support decreases. The roadway space is narrowed due to the large displacement on the side of the roadway toward the pillar, so the expansion of the roadway space must be made to meet production requirements.

4. Cable bolts can improve the flexibility of coal pillars by reducing the size of the plastic area (areas I, III) in the surrounding rock by providing great drag and tensile for the coal pillars. This method has the effect of increasing the pulling force based on the pulling capacity of cable bolts for collapse area III, controlling fracture zone I and stabilizing stable area II. This support method has shown the superiority of improving the load capacity of the coal pillar and the stability of the roadway.

As such, the solution to support roadways and coal pillars with rock bolts combined with long cable bolts in roofs and coal pillars is likely to ensure the most stable and safe roadways in the current support solutions in Vietnamese underground coal mines. Although in this method, the displacement on the floor is larger than the other solutions, it is not a great danger to the stability of the roadway.

\section{Literatura - References}

1. Zubov V. P. (2018). Applied technologies and current problems of resource-saving in underground mining of stratified deposits. Gornyi Zhurnal; 06: 16.

2. Dao Viet Doan, Bai Xia, Van Diep Dinh. (2019). Control technology for coal roadway with mudstone interlayer in Nui Beo coal mine. International Journal of GEOMATE, Vol.17, Issue 60, pp.259-266.

3. Dong Wang, Yujing Jiang, Xiaoming Sun, Hengjie Luan, Hui Zhang. (2019). Nonlinear Large Deformation Mechanism and Stability Control of Deep Soft Rock Roadway: A Case Study in China. Sustainability 2019, 11, 6243.

4. Mroz Z., Nawrocki P. (1989). Deformation and stability of an elasto-plastic softening pillar. Rock Mech Rock Eng 22:69-108.

5. Salamon MDG (1970). Stability, instability and design of pillar workings. Int J Rock Mech Min Sci Geomech Abstr 7:613-631.

6. Wattimena R., Kramadibrata S., Sidi I., Azizi M. (2013) Developing coal pillar stability chart using logistic regression. Int J Rock Mech Min Sci 58:55-60.

7. Li C., Xu JH, Pan JZ., Ma C. (2012). Plastic zone distribution laws and its types of surrounding rock in large-span roadway. Int J Mining Sci Technol 2012;22(1):23-8.

8. Bo Wang, Fuxing Jiang, Chao Wang, Bin Zhang. (2019). Experimental Study on the Width of the Reasonable Segment Pillar of the Extremely Soft Coal Seam in the Deep Mine. Geotechnical and Geological Engineering; volume 37. 2019, pages 4947-4957.

9. Li M., Mao XB., Yu YL., Li K., Ma C., Peng Y. (2012). Stress and deformation analysis on deep surrounding rock at different time stages and its application. Int J Mining Sci Technol 2012;22(3):301-6.

10. Зубов В. П. (1998). Метод оценки параметров областей с повышенной нарушенности пород кровли над краевыми частями угольного массива / В. П. Зубов, Г. И. Козовой, А. Б. Соколов. Доклады III Международной конференции "Горное оборудование, переработка минерального сырья, новые технологии, экология" / Санкт-Петербургский горный институт. СПБ, 1998. С. 44-50.

11. Lifeng Li, Weili Gong, Jiong Wang, Huilin Deng, Qianqian Jiang, Yan Liu. (2018). Coal Pillar Width Design in High-stress Gob-side Entry Driving. Journal of Engineering Science and Technology Review 11 (4) 52 - 60;

12. Wang Pengfei, Yoginder Chugh. (2019). Stability of Gate Roads Next to an Irregular Yield Pillar: A Case Study. Rock Mechanics and Rock Engineering 52:2741-2760; 
13. Wu Hai, Zhang Nong, Wang Weijun, Zhao Yiming, Cao Peng. (2015). Characteristics of deformation and stress distribution of small coal pillars under leading abutment pressure. Int J Min Sci Technol. Volume 25, Issue 6, November 2015, Pages 921-926.

14. Зубов В. П. (2013). Научная школа «разработка месторождений твердых полезных ископаемых»: этапы становления, основные результаты исследований, направления развития. Записки Горного института. Т.205. СПБ, 2013, С. 11-17.

15. Rocscience, 2016. Finite Element Analysis for Excavations and Slopes. <https://support.rocscience.com/hc/en-us/ categories/200373647-RS2f>.

16. https://www.dsiunderground.com.au/products/mining/rock-bolts.

17. Lifeng Li, Weili Gong, Jiong Wang, Huilin Deng, Qianqian Jiang, Yan Liu. (2018). Coal Pillar Width Design in High-stress Gob-side Entry Driving. Journal of Engineering Science and Technology Review 11 (4) (2018) 52 - 60;

18. Hongwei Zhang, Zhijun Wan, Zhaoyang Ma, Yuan Zhang. (2018). Stability control of narrow coal pillars in gobside entry driving for the LTCC with unstable overlying strata: a case study. Arabian Journal of Geosciences (2018) 11:665.

Poprawa nośności wąskich filarów i kontrola deformacji wyrobisk złożowych w ścianowym systemie- Studium przypadku w kopalni wegla kamiennego Khe Cham (Wietnam)

Obecnie stosowanie filarów węglowych do ochrony sąsiednich wyrobisk złożowych jest powszechna metoda przy eksploatacji systemem ścianowym w Wietnamie. Wymiary filarów jest istotna kwestiq dla stabilności wyrobisk złożowych. Aby zmniejszyć straty wegla, zwykle sq one projektowane w stylu waskich filarów, ale nadal musza zapewniać, że sąsiednie wyrobiska musza spełniać bezpieczne warunki. Stateczność wyrobisk i filarów weglowych jest związana z wieloma czynnikami, takimi jak techniczne właściwości fizyczno-mechaniczne górotworu, naprężenia i metody podparcia. Przeanalizowano konstrukcję nośna filara węglowego i skały otaczajacej chodniki wykazano, że wzmocnienie podparcia wyrobisk i polepszenie nośności filarów węglowych może kontrolować odkształcenia otaczającej skały. W artykule, przedstawiono wyniki badania dotyczącego stateczności wyrobisk $i$ matych filarów w ścianowym systemie. Uwzględniono czynniki stabilizujące, w szczególności stan naprężeń w filarach oraz odkształcenie chodników. Wykorzystujac metodę symulacji numerycznej, przeanalizowano i oceniono naprężenie $w$ filarach weglowych oraz odkształcenie sąsiednich chodników przy różnych rozwiązaniach podporowych. Ponieważ śruba linowa może poprawić elastyczność filarów, na przykład: zmniejszenie rozmiaru obszaru $z$ tworzywa sztucznego po obu stronach filara; zwiększenie stabilności filara węglowego w obszarze rdzeniowym poprzez zapewnienie dużego oporu i rozciągliwości filarów; przyczynianie się do poprawy mocowania punktu kotwienia śruby do skał. Uzyskane wnioski moga dostarczyć rozwiązania dla poprawy efektywności wydobycia i bezpieczeństwa pracy w podziemnych kopalniach wegla kamiennego.

Słowa kluczowe: podparcie wyrobisk złożowych, modelowanie numeryczne, przemieszczenie górotworu, stateczność filarów węglowych 